\section{Family first}

Better sequencing techniques are enabling some scientists to take personal genomics literally.

$\mathrm{W}$ hen Bea Rienhoff was born nearly 10 years ago, her father Hugh and her doctors immediately noticed some worrying signs. Her long fingers and toes curled inwards. Her eyes were spaced just a bit wider than normal, and she was floppy - not like the clenched little bundles of energy her two brothers were at birth. In the joy of the moment, Rienhoff put these nagging concerns aside. But as Bea grew and failed to put on much muscle, he became increasingly worried that she might have a genetic syndrome, one that might lead to dangerous complications with her heart.

Like any parent of a child with a mysterious undiagnosed disease, Rienhoff wanted answers and was willing to do nearly anything to get them. Bea was fortunate: her dad had trained in clinical genetics in the 1980s under Victor McKusick, widely considered the father of the field. And Rienhoff's subsequent work in biotechnology and venture capital filled his address book with the names of movers and shakers in the burgeoning field of genomics.

Rienhoff and Bea appeared on the cover of Nature in 2007 as his personal anguish and professional abilities combined in unlikely fashion (see Nature 449, 773-776; 2007). He had purchased used laboratory equipment, set it up in his basement and prepared several of Bea's genes for sequencing. That failed to provide an answer. So he reached out to colleagues at Illumina, a genome-sequencing company in San Diego, California, who took the search to the next level by sequencing RNA and DNA from him, Bea, her siblings and her mother.

That work seems to have borne fruit, and Rienhoff is back in the pages of Nature this week (see page 418). He and his volunteer collaborators are confident that they have found the mutation responsible for Bea's condition. Bea is still skinny, but otherwise healthy.

Rienhoff's journey into such personal genomics made some people uncomfortable, especially in the early days. Back then, genomics had never been used successfully to unpick the genetic causes of a new disease in a single patient. Usually one or more families with multiple affected members were needed. More worrisome, perhaps, was

Rienhoff's closeness to his study subject. Although a passion for one's work is a feature of good science, people often draw the line when the subject is a family member.

Today, whole- and partial-genome sequencing has been used several times to discover the gene or genes responsible for a new disease. And many high-profile success stories have involved family members of those close to the action.

For instance, when colleagues of geneticist Lynn Jorde at the University of Utah in Salt Lake City were looking for a rare disease on which to test whole-genome sequencing, he suggested asking his two adult stepchildren, Heather and Logan Madsen. They had been diagnosed with Miller syndrome, which affects development of the face

"What Hugh Rienhoff has done is beyond the reach of most parents for now." and limbs, among other features. In 2009, Heather, Logan and their mother and father became the first family in the world to have their entire genomes sequenced. Researchers identified a causative mutation for the disorder as a result (see Nature 478, 22-24; 2011). James Lupski, a geneticist at Baylor College of Medicine in Houston, Texas, has a rare form of the nerve disorder Charcot-Marie-Tooth disease. He and his collaborators sequenced his entire genome and compared it with that of his brother, together with partial sequences from other family members, to identify new mutations associated with the disease (see Nature http://doi.org/cwc5wv; 2010).

And Retta Beery and her husband Joe, chief information officer at sequencing company Life Technologies in Carlsbad, California, convinced a team at Baylor College of Medicine to sequence their teenage twins Alexis and Noah to refine their diagnosis of dystonia, a muscle-tone disorder that affects movement. Physicians found that the twins had an extra mutation that complicated their disease, and which pointed to better treatment options (see Nature http://doi.org/ cj66mr; 2011).

For Rienhoff, starting such a quest today would probably have been easier. Many paediatric hospitals are gearing up to offer whole- or partial-genome sequencing to families such as his. Still, Rienhoff suspects that might not be enough. It took him years to find the gene responsible in his daughter's case, and his work benefited greatly from his connections in the community and the attendant publicity. Hugh, like his daughter, is special, and what he has done is probably beyond the reach of most parents for now. That won't be the case for long.

\section{How do you sleep?}

\section{Modern sleep patterns cause ill health, soit is} time to work out how much rest we really need.

$\mathrm{S}$ leep, as Shakespeare noted in Macbeth, is the chief nourisher in life's feast. But some go hungrier than others, and their ranks are increasing. Some 70 million people in the United States alone are thought to suffer from insomnia or another pathology of sleep.

Sleep is universal, but there is decent evidence that we are doing it wrong. That we need eight hours of sleep a night to function is a myth; that we need our shut-eye in one continued bout is unlikely. Before artificial lights, people went to bed earlier. And it was once more common to have two night-time sleeps, separated by a productive period of wakefulness.

Scientists cannot say for sure how much sleep we need, or when we should take it. As chronobiologist Till Roenneberg points out in a Comment on page 427, part of the reason is that most studies of sleep are done in laboratories. He proposes a radical solution: a

US\$30-million global human sleep project that would start with online logs of the sleep habits of millions of volunteers and finish with DNA tests to work out where those habits come from.

"The practice of going to sleep and waking at unnatural times could be the most prevalent high-risk behaviour in modern society," says Roenneberg. Many workers at present, he says, could suffer from a form of social jet lag, forced to shuffle sleep patterns between the conflicting time zones of working and work-free days. That could cause poor health - both physical and mental. The solution would be a profound change: restructure work and school schedules to better suit the biological clocks of the majority of the population, once we work out what they are.

The modern world fragments time. We work on call and watch 24-hour news. Television is on-demand and breakfast usually available all day. We sleep when we can, if we can. Sleep has become another demand on us, and one that we like to allot to a specific window of our daily diary. That is a difficult habit to break for scientists as much as anybody, given their often long hours and frequent travel.

$\rightarrow$ NATURE.COM To comment online, click on Editorials at: go.nature.com/xhunqv
People in many countries get as much as two hours less sleep a night than their ancestors did a century or so ago. That must have a consequence. Lack of sleep may not make our hungry lives longer, it just feels that way. 